Prekariat - perspektywa katolickiej nauki społecznej, red. J. Mazur OSPPE, ks. Ł. Marczak, Kraków 2017

(Spotkania Naukowe Wykładowców Katolickiej Nauki Społecznej, XIII), s. 137-148.

DOI: http://dx.doi.org/10.15633/9788374385985.08

ks. Piotr Mazurkiewicz

Uniwersytet Kardynała Stefana Wyszyńskiego w Warszawie

\title{
Od proletariatu do prekariatu. Refleksje na kanwie społecznej troski COMECE
}

Książka Guy Standinga Prekariat. Nowa niebezpieczna klasa opublikowana została w 2011 roku. Wcześniej nie mówiło się o prekariacie. Nie oznacza to, że nie istniały problemy społeczne kojarzone obecnie z tym nowym terminem ani że nie uwzględniano zagadnienia ubóstwa w unijnej polityce. Używano jednak bardziej tradycyjnych pojęć, koncentrując się przy tym na kwestiach, które są specyficznie związane z unijną percepcją kwestii społecznej. Osobiście nie jestem przekonany do konieczności wprowadzania nowej terminologii do deskrypcji nowej kwestii społecznej, zwłaszcza gdy zdają się one wpisywać w neomarksistowski sposób opisu świata ${ }^{1}$.

W latach 2008-2012 COMECE monitorowało na bieżąco politykę i prawo unijne w rzeczonym zakresie. Ponadto opublikowało w tym czasie trzy większe dokumenty:

- Do not Deny Justice to Your Poor People. Proposals for Combating Poverty and Social Exclusion in the EU (2010) (wspólnie z Caritas Europa, the Church and Society Commission of the Conference of European Churches i Eurodiaconia);

1 Przykładem takiego podejścia jest książka Jarosława Urbańskiego, Prekariat i nowa walka klas, Warszawa 2014. 
- A European Community of Solidarity and responsibility. A Statement of the COMECE Bishops on the EU Treaty Objective of a Competitive Social Market Economy (2011);

- Soziale Markwirtschaft in der Europäischen Union, red. P. Schallenberg, P Mazurkiewicz, Paderborn-MünchenWien-Zürich 2012.

COMECE zainicjowało także powstanie European Sunday Alliance, europejskiego stowarzyszenia skupiającego związki zawodowe, organizacje kościelne i pozarządowe, stawiające sobie za cel obronę niedzieli jako dnia w Europie tradycyjnie wolnego od pracy. Korespondowało to z pracami nad nową dyrektywą o czasie pracy.

\section{Europejski rok walki z ubóstwem i społecznym wykluczeniem}

Dokument, który chciałbym w tym miejscu omówić: Do not Deny Justice to Your Poor People, powstał w związku z ogłoszeniem przez UE roku 2010 Europejskim Rokiem Walki z Ubóstwem i Społecznym Wykluczeniem. Autorzy zwracają uwagę, że cechą charakterystyczną współczesnej globalnej gospodarki wolnorynkowej są, $\mathrm{z}$ jednej strony, koncentracja bogactwa, $\mathrm{z}$ drugiej zaś, powszechność zjawiska głodu i ubóstwa. Od kontrastów tego typu nie jest wolny także jeden $\mathrm{z}$ najbogatszych regionów świata, jakim jest Unia Europejska ${ }^{2}$. Nie przypadkiem jednym z głównych celów strategii Europe 2020 jest zwalczanie ubóstwa i społecznego wykluczenia, a konkretnie zmniejszenie w UE do 2020 roku liczby ludzi zagrożonych ubóstwem i społecznym wykluczeniem o przynajmniej 20 milionów (cel 5). Komisja Europejska stwierdza, że w 2008 roku ponad 80 mln osób w UE (16,5 proc. całej ludności

2 OECD Data, Income inequality, https://data.oecd.org/inequality/income-inequality.htm (29.12.2016). 
Unii) żyło poniżej progu ubóstwa. Ponad połowę tej grupy stanowią kobiety, a $20 \mathrm{mln}$ to dzieci. Kryzys gospodarczy jeszcze pogorszył tę sytuację, gdyż dotknął przede wszystkim osoby najsłabsze.

Najbardziej doświadczone bezrobociem - czytamy w Komunikacie Komisji Europejskiej - są obecnie osoby młode, migranci i osoby o niskich kwalifikacjach, często zależni od tymczasowej i słabo wynagradzanej pracy. W związku z tym są oni narażeni na pogorszenie warunków życia. Konkretnie, co piąta młoda osoba na rynku pracy jest bezrobotna. Wskaźnik bezrobocia dla osób niebędących obywatelami UE wynosi 11 punktów procentowych więcej niż wskaźnik dla obywateli UE; osoby o niskich kwalifikacjach zagrożone są bezrobociem dwukrotnie bardziej niż osoby o wysokich kwalifikacjach. Tak zwani „ubodzy pracujący” (working poor) stanowili w 2008 roku 8 proc. ludności czynnej zawodowo, natomiast zagrożenie ubóstwem znacznie wzrosło w przypadku bezrobotnych, z 39 proc. do 44 proc. od 2005 roku. Ponadto 8 proc. Europejczyków żyje w skrajnie trudnych warunkach materialnych i nie może pozwolić sobie na zaspokojenie wielu potrzeb uważanych w Europie za podstawowe do prowadzenia życia na przyzwoitym poziomie, takich jak posiadanie telefonu lub odpowiednie ogrzewanie. W najbiedniejszych państwach wskaźnik ten przekracza 30 proc.. Ponad 9 proc. Europejczyków w wieku produkcyjnym żyje w gospodarstwach domowych, w których nikt nie pracuje ${ }^{3}$.

${ }^{3}$ Komunikat Komisji do Parlamentu Europejskiego, Rady, Europejskiego Komitetu Ekonomiczno-Społecznego oraz Komitetu Regionów, Europejska platforma wspótpracy w zakresie walki z ubóstwem i wykluczeniem społecznym: europejskie ramy na rzecz spójności społecznej i terytorialnej, http://eur-lex. europa.eu/legal-content/PL/TXT/PDF/?uri=CELEX:52010DC0758\&from$=\mathrm{EN}$ (2.01.2017). Dane sprzed 8 lat należałoby teraz zestawić $\mathrm{z}$ aktualnymi danymi, aby móc ocenić, jak dalece udało się politykom zrealizować stawiane sobie cele unijne. 
Mówiąc o skali ubóstwa w Unii, trzeba jednak pamiętać, że nie chodzi tu o ubóstwo absolutne (stan niezaspokojenia minimalnych potrzeb biologicznych), które zdecydowanie zmniejsza się w UE, ale o ubóstwo względne, odniesione do przeciętnego poziomu życia w danym kraju, mierzonego na ogół wysokością przeciętnych dochodów. Nie chodzi zatem o dostęp do dóbr i usług podstawowych dla życia, ale o standard życia odniesiony do średniej unijnej czy krajowej.

\section{Kryzys najsilniej uderza w najsłabszych}

Autorzy kościelnego dokumentu zwracają uwagę, że choć Europa jest bogata, to jednak pełna nierówności, co oznacza, że aktualny model rozwoju należy uznać za niezrównoważony. W dłuższej perspektywie może on doprowadzić do głębokiego kryzysu ekonomicznego i konfliktów społecznych ${ }^{4}$. Doświadczany kryzys ekonomiczny i finansowy nie pojawił się przypadkowo, ale jest efektem błędnych decyzji podejmowanych przez rządy państw oraz w sektorze finansowym. 25 lat prosperity uśpiło bowiem czujność decydentów, którzy naiwnie uwierzyli w stabilny, efektywny i samoregulujący się wolny rynek, na którym pieniądz rodzi pieniądz, a bogactwo rodzi bogactwo. Tymczasem światowa gospodarka została mocno uzależniona od spekulacyjnego systemu finansowego, niesprawiedliwego przede wszystkim wobec osób, które utrzymują się wyłącznie z pracy. Na tych samych błędnych założeniach (samoregulujący się rynek, prymat kryteriów ekonomicznych we wszystkich dziedzinach życia, znaczenie przypisywane zyskowi i wzrostowi gospodarczemu) budowano także politykę ekonomiczną UE. Kryzys jednak jest przede wszystkim kryzysem wartości, pogłębionym przez brak zaufania do instytucji finansowych

4 Por. Do not Deny Justice to Your Poor People. Proposals for Combating Poverty and Social Exclusion in the EU, 2010, s. 14. 
i politycznych. Ukazuje on, że w polityce gospodarczej pomylono środki z celami. Wzrost, konkurencyjność i rynek nie są celami samymi w sobie, ale środkami, które powinny służyć poprawie życia ludzi i budowie spójnego społeczeństwa, tzn. wzrostowi dobra wspólnego. Deregulacja rynku prowadzi natomiast do osłabienia pozycji celów społecznych i politycznych w polityce ekonomicznej. Wzrost PKB nie może być mylony z rozwojem społecznym. Kryzys ekonomiczny i finansowy uderza najmocniej w najsłabszych.

Miliony ludzi utraciły pracę albo musiały zaakceptować redukcję pensji czy podjąć niepewne zatrudnienie (precarious jobs). Ponieważ finanse publiczne zostały poważnie ograniczone, poziom wydatków socjalnych został niejednokrotnie obniżony, a obcięcie zasiłków społecznych pogorszyło warunki życia najbiedniejszych grup. Nadmierne zadłużenie osób i rodzin staje się powszechnym problemem w wielu krajach. Bezrobocie młodych wzrosło dramatycznie i zagraża przyszłości całego nowego pokolenia ${ }^{5}$.

Dalekosiężnym skutkiem tego procesu może być zwiększenie fragmentacji społeczeństwa.

W tym samym jednak czasie, aby spowodować ustabilizowanie się systemu, wydano miliardy euro na ratowanie upadających banków. Są to pieniądze, które będą musiały spłacać następne pokolenia podatników. Podobnie miliardy euro wydano na ratowanie wiarygodności państw - dłużników strefy euro. Pozostaje to $\mathrm{w}$ wielkim kontraście $\mathrm{w}$ stosunku do pieniędzy przeznaczonych na ochronę osób najbardziej zagrożonych konsekwencjami kryzy$\mathrm{su}^{6}$. W dokumencie podejmuje się także szczególną refleksję nad dziedziczeniem ubóstwa („zamknięty krąg ubóstwa”), charakterem ubóstwa kobiet oraz nad indywidualizacją ryzyka (uwarun-

${ }^{5}$ Do not Deny Justice to Your Poor People..., dz. cyt., s. 15.

${ }^{6}$ Por. Do not Deny Justice to Your Poor People..., dz. cyt., s. 16. 
kowanie dostępu do zasiłków socjalnych, indywidualna odpowiedzialność za przyszłą emeryturę itp. $)^{7}$.

\section{Wielowymiarowa koncepcja ubóstwa}

Z chrześcijańskiego punktu widzenia, podkreślają autorzy dokumentu, rozróżnienie między względnym a absolutnym ubóstwem nie jest wystarczające. Ubóstwo bowiem jest zjawiskiem wielowymiarowym, przy czym ludzie wierzący szczególnie podkreślają relacyjny i duchowy aspekt ubóstwa. Jednak nawet rozważając ubóstwo w kategoriach braku wystarczających środków finansowych, należy zauważyć, że może to powodować niedostatek w zakresie zaspokajania bardzo różnych potrzeb człowieka: nie tylko braku żywności czy godnego mieszkania, ale także dostępu do służby zdrowia, edukacji, integracji z grupą zawodową czy społeczną. W ramach analizy zjawiska ubóstwa powinno się brać pod uwagę także status prawny osoby (rezydent/migrant), rodzinę pochodzenia („dziedzictwo społeczne”), a ponadto psychologiczne, kulturowe, etyczne i duchowe aspekty ubóstwa. Uwzględniwszy bogatszą koncepcję ubóstwa dostrzegamy, że granice między bogatymi i ubogimi w każdym z tych aspektów mogą przebiegać $\mathrm{w}$ innym miejscu.

Na ogół główną, wskazywaną w badaniach, w Europie strukturą wsparcia jest rodzina. Od jej kondycji i siły więzów rodzinnych zależy integracja społeczna jednostki. Samotność jako forma ubóstwa relacyjnego doświadczana jest zatem przez ludzi o bardzo różnym statusie materialnym. Mamy wielu ubogich materialnie, którzy pomimo to są dobrze zintegrowani społecznie, i wielu bogatych, którzy są ludźmi społecznie wykluczonymi. Pisał o tym św. Jan Paweł II, podkreślając, że w Europie wielu ludzi żyje bez

\footnotetext{
${ }^{7}$ Por. Do not Deny Justice to Your Poor People..., dz. cyt., s. 18-20.
} 
jakiegokolwiek emocjonalnego zaplecza, będąc „pozbawieni uczuciowego oparcia"s.

Bogatsza koncepcja ubóstwa prowadzi do refleksji nad pytaniem, czy ubóstwo samo w sobie zawsze jest negatywnym zjawiskiem, a jeśli nie, to $\mathrm{w}$ jakim sensie może być ono twórcze. Cywilizacja konsumpcyjna powoduje - zauważają autorzy dokumentu - że ludzie poddani zewnętrznej presji gotowi są zaprząc się $\mathrm{w}$ „hedonistyczny kierat”, także poważnie się zadłużając, aby tylko zwiększyć własną konsumpcję. Ostatecznie jednak konsumpcyjny styl życia prowadzi do rozczarowania. Pogoń za dobrami materialnymi pochłania czas, który w innym przypadku byłby przeznaczony na pogłębienie relacji rodzinnych czy na refleksję nad głębszym znaczeniem ludzkiego życia, na medytację i modlitwę. Pragnienie posiadania i natychmiastowej gratyfikacji przyczynia się do relacyjnego i duchowego ubóstwa ${ }^{9}$.

Interesującym komentarzem może być eksperyment na myszach przeprowadzony w 1968 roku przez Johna Calhouna. Umieścił on cztery pary myszy w liczącym $2,7 \mathrm{~m}^{2}$ terrarium, zapewniając im obfitość jadła i napoju. W tych korzystnych dla rozwoju warunkach populacja myszy gwałtownie rosła, podwajając się co 55 dni, aż do 315 dnia, kiedy to osiągnęła 620 osobników. Potem nastąpiło znaczące spowolnienie przyrostu naturalnego. Populacja podwajała się co 145 dni. Po 600 dniach urodziła się ostatnia żywa mysz. Populacja osiągnęła wówczas 2200 osobników. Między 315 a 600 dniem nastąpiło załamanie struktury społecznej i normalnych społecznych zachowań. Objawiało się to między innymi ranieniem młodych osobników, wzrostem zachowań homoseksualnych, niezdolnością dominujących samców do obrony swojego terytorium i swoich samic, agresywnymi zachowaniami samic itp. Po 600. dniu samice przestały się rozmnażać, samce wycofały się całkowicie, nie angażując się w zaloty i walki.

8 Jan Paweł II, adh. apost. Ecclesia in Europa (28.06.2003), nr 8.

9 Por. Do not Deny Justice to Your Poor People..., dz. cyt, s. 20-21. 
Ostatecznie populacja dobrze odżywionych myszy wyginęła. Los mysiej populacji Calhoun postrzegał jako metaforę cywilizacji konsumpcyjnej, która - jego zdaniem - także zmierza ku naturalnej śmierci nie $\mathrm{z}$ braku, lecz z nadmiaru ${ }^{10}$.

Człowiek włączony w „konsumpcjonistyczny kierat” obraca się w przeciwnym kierunku niż świat wprawiany w ruch przez chrześcijańskie ideały, zgodnie z którymi wartości człowieka nie mierzy się miarą sukcesu ${ }^{11}$. Chrześcijaństwo, poczynając od samego Jezusa, który „będąc bogatym, dla was stał się ubogi, aby was swoim ubóstwem ubogacić" (2 Kor 8, 9), poprzez chrześcijańskich mnichów i mniszki, składających ślub ubóstwa, na czele ze św. Franciszkiem z Asyżu, naucza pozytywnej wizji ubóstwa rozumianego jako wartość duchowa. Robi to także poprzez stałe nauczanie na temat miłości do ubogich, które przybrało w ostatnich dziesięcioleciach formę „opcji preferencyjnej na rzecz ubogich” ${ }^{12}$. Analiza chrześcijańska w zasadniczy sposób odbiega od analizy marksistowskiej czy neomarksistowskiej, opartej na materializmie ${ }^{13}$. Ubóstwo, rozumiane jako dobrowolnie wybrana prostota życia, nabiera szczególnego znaczenia w kontekście zanieczyszczenia środowiska naturalnego. W encyklice Laudato si’ papież Franciszek mówi wręcz o takiej potrzebie zmiany stylu życia, którą można by słusznie nazwać „nawróceniem ekologicznym” ${ }^{14}$. Chrześcijańskie podejście stawia zatem przed politykami i osobami odpowiedzialnymi za życie gospodarcze zadanie, by zwalczając ubóstwo, nie walczyli jednocześnie z duchem ubóstwa i nie promowali materialistycznej wizji człowieka i społeczeństwa.

${ }^{10}$ Por. Wikipedia, John B. Calhoun mouse experiments, https://en.wikipedia. org/wiki/John_B._Calhoun\#Mouse_experiments (29.12.2016).

11 Por. Do not Deny Justice to Your Poor People..., dz. cyt., s. 21.

12 Por. Kongregacja Nauki Wiary, Instrukcja o chrześcijańskiej wolności i wyzwoleniu (22.03.1986), nr 66-70 i in.

13 Por. Kongregacja Nauki Wiary, Instrukcja o niektórych aspektach „teologii wyzwolenia (6.08.1984), nr 39-91 i in.

${ }^{14}$ Franciszek, enc. Laudato si' (24.05.2015), nr 216-221. 


\section{Czternaście postulatów}

Omawiany dokument zamyka lista czternastu konkretnych postulatów skierowanych pod adresem unijnych polityków. Są one streszczone w zamieszczonym na początku dokumentu executive summary. Lista zaczyna się od przypomnienia konieczności implementacji Europejskiej Karty Społecznej, do której odwołuje się preambuła Traktatu o Unii Europejskiej. Art. I.30 EKS głosi: „Każdy ma prawo do ochrony przed ubóstwem i marginalizacją społeczną”. Art. 3 ust. 3 TUE proklamuje, że UE „zwalcza wykluczenie społeczne". Natomiast art. 9 Traktatu o funkcjonowaniu UE zawiera horyzontalną klauzulę socjalną:

Przy określaniu i realizacji swoich polityk i działań Unia bierze pod uwagę wymogi związane ze wspieraniem wysokiego poziomu zatrudnienia, zapewnianiem odpowiedniej ochrony socjalnej, zwalczaniem wykluczenia społecznego, a także $\mathrm{z}$ wysokim poziomem kształcenia, szkolenia oraz ochrony zdrowia ludzkiego.

Wobec powyższego pierwszy postulat głosi konieczność włączenia odrębnego paragrafu socjalnego do rocznej strategii politycznej Komisji Europejskiej oraz do raportu ogólnego Komisji Europejskiej dla Parlamentu Europejskiego. Ponadto wnosi się o ustanowienie grupy ekspertów społecznych, której celem byłoby coroczne sprawdzanie sposobu implementacji klauzuli socjalnej (1). Podobnie, zadaniem Przewodniczącego Rady Europejskiej byłoby przyjrzenie się implementacji klauzuli socjalnej $\mathrm{w}$ raporcie dla Parlamentu Europejskiego każdorazowo po spotkaniu Rady (2). Również Agencja Praw Podstawowych w swoim rocznym programie pracy powinna poświęcić szczególną uwagę Rozdziałowi IV (Solidarność) Karty (3). Unia Europejska oraz Państwa Członkowskie powinny zapewnić wszystkim obywatelom dostęp do odpowiedniej jakości usług socjalnych i zdrowotnych 
(4). Komisja Europejska wraz z Państwami Członkowskimi powinny opracować system gwarantujący płacę minimalną, aby wyeliminować zjawisko „pracy śmieciowej” (working poor) i zapewnić każdemu pensję gwarantującą życie na godnym poziomie (5). Ponadto Państwa Członkowskie powinny podjąć wysiłki w kierunku wprowadzenia minimalnego dochodu, umożliwiającego upodmiotowienie jednostki i jej pełne uczestnictwo w życiu społecznym (6). Podobnie powinno się opracować długofalową wizję polityczną $\mathrm{w}$ miejsce stosowanych obecnie doraźnych środków, stawiającą sobie za cel całkowity zanik zjawiska bezdomności i zapewnienie każdemu godnych warunków mieszkaniowych (7). Autorzy raportu zwracają uwagę, że problem bezdomności jest systematycznie nieobecny w statystykach Eurostatu, w związku $\mathrm{z}$ czym Unia nie dysponuje w tym zakresie wiarygodnymi statystykami ${ }^{15}$. Kolejny postulat dotyczy konieczności zerwania z modelem gospodarki opartym na nadmiernej konsumpcji i chciwości, i promowania w jej miejsce alternatywnego modelu opartego na umiarkowaniu i hojności (8). Konieczna jest również zmiana sposobu pomiaru stanu gospodarki, wprowadzenie nowej metodologii i nowych wskaźników, które uwzględniałyby między innymi wpływ ubóstwa i społecznego wykluczenia na kobiety i mężczyzn (9). Nowe podejście do gospodarki powinno się wiązać $\mathrm{z}$ dowartościowaniem wolontariatu i nieopłacanej pracy (unpaid work), zwłaszcza wykonywanej w rodzinie i w sektorze opiekuńczym, np. poprzez oferowanie ubezpieczeń zdrowotnych, prawa do emerytury czy uznanie nieformalnych kwalifikacji zdobytych w trakcie jej wykonywania (10). Paradoksem jest bowiem, że praca kobiety gotującej obiad dla domowników czy sprzątającej mieszkanie nie pojawia się w kalkulacjach budżetu narodowego, a w związku z tym nie przyczynia się oficjalnie do wzrostu produktu narodowego, podczas gdy ta sama praca wykonywana dla sąsiada powoduje już wzrost PKB. Wymuszone niedawno przez

15 Por. Do not Deny Justice to Your Poor People..., dz. cyt, s. 32. 
Komisję Europejską na Państwach Członkowskich wliczenie do dochodu narodowego obrotu czarnorynkowego pokazuje, że zadanie takie nie jest niemożliwe do wykonania. Kolejny postulat dotyczy konieczności wsparcia przez Państwa Członkowskie rodzin znajdujących się w sytuacji ryzyka ubóstwa. Możliwe jest to choćby poprzez obniżenie stawek VAT na produkty dla niemowląt i małych dzieci, zasiłki na każde dziecko, promowanie modelu rodziny przynajmniej 2 plus $3 \mathrm{czy} 10 \mathrm{dni}$ w roku płatnego urlopu dla każdego z rodziców, co uelastyczniłoby czas ich pracy (11). Innym oczekiwaniem jest ochrona w UE niedzieli jako dnia wolnego od pracy. Byłoby to nie tylko kultywowaniem europejskiej tradycji, ale także przypominałoby, że to praca jest dla człowieka, a nie człowiek dla pracy (12). Aby wzbogacić refleksję nad kwestią ubóstwa w Europie, instytucje unijne powinny prowadzić dialog z Kościołami i wspólnotami religijnymi, zgodnie z art. 17 ust. 3 TFUE, oraz powołać do życia Europejską Platformę ds. Walki z Ubóstwem (13). Ostatni zgłoszony w dokumencie postulat dotyczy konieczności przeznaczenia 10 proc. rocznego unijnego budżetu, który sam w sobie stanowi 1 proc. unijnego $\mathrm{PKB}$, na walkę $\mathrm{z}$ ubóstwem. Środki takie powinny być przewidziane w ramach Europejskiego Funduszu Rozwoju Regionalnego, Europejskiego Funduszu Socjalnego i Funduszu Spójności. Urzędnicy unijni zajmujący się ubóstwem i wykluczeniem społecznym - postulują autorzy dokumentu - powinni mieć możliwość nabycia osobistego doświadczenia w pracy z ludźmi ubogimi (14).

Przypomnijmy raz jeszcze, że Europa jest jednym z najbogatszych regionów świata. Ubóstwo w Europie nie jest zatem konsekwencją braku środków, ale niewłaściwego dysponowania tym bogactwem, które się posiada. Chrześcijaństwo, promując preferencyjną opcję na rzecz ubogich i kulturę miłosierdzia, niewątpliwie może się przyczynić do lepszej organizacji gospodarki i polityki społecznej w Europie. Mimo iż jest to ważna misja, nie jest to jednak główna misja Kościoła. Węgierski pisarz Sándor Márai pisał: „ jeśli z chrześcijańskiej pojęciowości usunąć eschatologię, 
to tak naprawdę nie pozostanie nic prócz socjalizmu sformułowanego w sposób luźny i rozwodniony, więcej - pozostanie raczej już tylko pauperyzm" ${ }^{\prime 6}$. Włączając się zatem w walkę z ubóstwem i społecznym wykluczeniem, także w Kościele trzeba być bardzo ostrożnym, by przypadkiem nie zwalczać samego ducha ubóstwa i by nie tracić z pola widzenia głównej racji istnienia Kościoła, tzn. misji zbawienia człowieka.

\footnotetext{
16 S. Marai, Trzydzieści srebrników, Warszawa 2016, s. 21.
} 